\title{
ANALISIS KELAYAKAN DAN STRUKTUR PASAR RUMPUT LAUT DI DESA SANDI KECAMATAN KALEDUPA SELATAN KABUPATEN WAKATOBI
}

\author{
Wa Ode Alzarliani \\ Program Studi Agribisnis Fakultas Pertanian \\ Universitas Muhammadiyah Buton \\ Jln. Betoambari No. 36 Baubau \\ e-mail: waodealzalian@yahoo.com
}

\begin{abstract}
The problems in this study are (1) how much income earned by farmers from seaweed cultivation activities in Sandi Village, South Kaledupa District (2) How much is the feasibility value of seaweed cultivation by farmers (3) How is the structure of the seaweed market in the Village South Kaledupa District. This research was carried out with the aim to determine (1) the income received by seaweed farmers (2) to determine the feasibility value of seaweed farming (3) to determine the seaweed market structure in Sandi Village, South Kaledupa District. The population in this study were all farmers who cultivated seaweed which amounted to 50 people. Determination of respondents is done by census method bv taking all farmers totaling 50 respondents. The results showed that the average income obtained by farmers within 6 months amounted to IDR 5,576,000 with an average rope length of 1277 meters used by farmers, with an income of IDR 929,333 per capita per month. That seaweed business is feasible to be cultivated and developed. The market structure faced by each marketing agency for seaweed in Sandi village is the same. Farmers, and village collectors face an oligopsony market structure. Dry seaweed produced by respondents after being sold to exporters, the seaweed sold back to the Industry in Surabaya to be managed and processed further so that the market structure faced by large traders (exporters) lead to the oligopoly market.
\end{abstract}

Keywords: income, feasibility, market structure, seaweed.

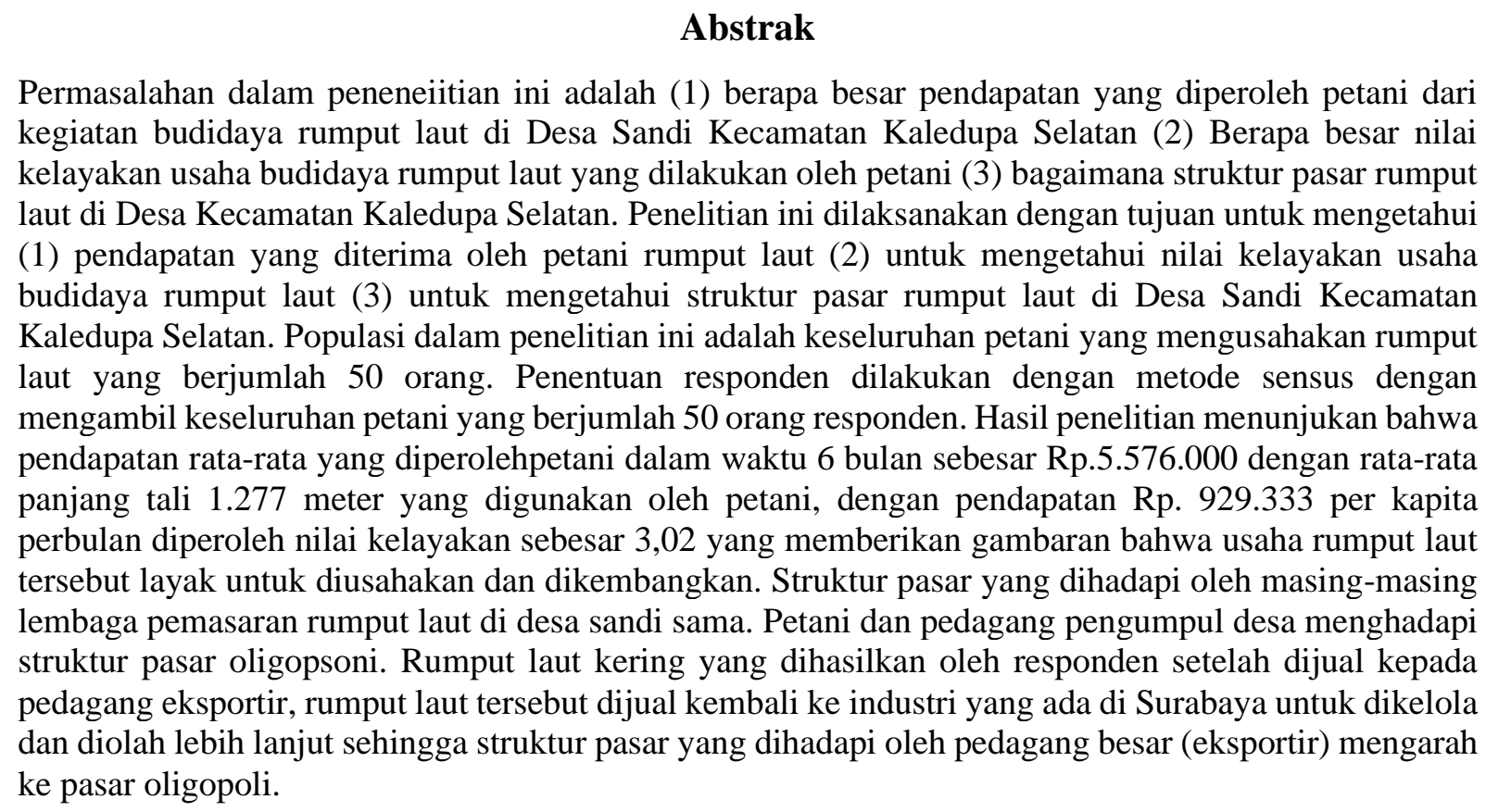


Kata kunci: Pendapatan, kelayakan, stuktur pasar, rumput laut

\section{PENDAHULUAN}

Dalam pembangunan di wilayah pesisir, salah satu pengembangan kegiatan ekonomi yang sedang digalakan pemerintah adalah pengembangan budidaya rumput laut. Melalui program ini diharapkan dapat merangsang terjadinya pertumbuhan ekonomi wilayan akibat meningkatnya pendaptan masyarakat.

Pengembangan budidaya rumput laut di Indonesia dirintis sejak tahun 1980-an dalam upayamerubah kebiasaan penduduk pesisir dari pengambilan sumber daya alam kearah budiadaya laut yang ramah lingkungan dan usaha budidaya ini dapat meningkatkan pendapatan masyarakat pembudidaya juga dapat digunakan memepertahankan kelestarian lingkungan perairan pantai (Ditjenkan Budidaya, 2004).

Pengembangan budidaya rumput laut merupakan salah satu alternatif pemberdayaan masyarakat pesisir yang mempunyai keunggulan dalam hai: (1) produk yang dihasilkan mempunyai kegunaan yang beragam, (2) tersedianya lahan untuk budiadaya yang cukup luas serta, (3) mudahnya teknologi budidaya yang diperlukan. (Departemen Kelautan dan Perikanan, 2001).

Perairan Kepualauan Wakatobi seluas 1.390.000, Ha ditunjuk berdasarkan Keputusan Menteri Kehutanan No.393/Kpts- VI/1996 Tgl 30 Juli 1996 dan ditetapkan berdasarkan Keputusan Menteri Kehutanan No. 7651/Kpts- 11/2002 tanggal 19 Agustus 2002 telah ditetapkan sebagai kawasan Peiestarian Alam yaitu Kawasan Konservasi Laut Taman Nasional Wakatobi yang meliputi seluruh Perairan Pulau Wangi-Wangi, Kaledupa, Tomia, Binongko, Runduma dan Perairan pulau Moromaho.

Sesuai dengan Undang- Undang No. 5 tahun 1990 tentang Konservasi Sumber Daya Alam Hayati dan Ekosistemnya, Pengelolaan Kawasan Taman Nasional dikelola dengan sistem Zonasi, maka setiap orang atau badan yang melakukan kegiatan/usaha didalam kawasan Taman Nasional harus sesuai dengan fungsi dan peruntukan setiap zona.

Zonasi Taman Nasional Wakatobi ditunjuk sesuai dengan Surat Keputusan Direktur Jenderal Perlindungan Hutan dan Pelestarian Alam No. 198/Kpts/DJ-VI/1 997 dan telah direvisi serta ditetapkan melalui surat Keputusan Direktorat Jenderal Perlindungan Kutan dan Konservasi Alam Nomor: SK. 149/IV-KK/2007 tanggal 23 Juli 2007 terdiri dari:

a) Zona Inti seluas: 1.3000 ha

b) Zona Pelindung Bahari seluas: 36.450 ha

c) Zona Pariwisata seluas: 6.180 ha

d) Zona Pemanfaatan Lokal: 804.000 ha

e) Zona Pemanfaatan Umum seluas: 495.700 ha

f) Zona Khusus Daratan seluas: 6.370 ha.

Penataan zonasi pada kawasan Tanaman Nasional Wakatobi diperlukan dalam rangka pengelolaan kawasan dan potensi sumber daya alam hayati dan ekosistemnya secara efektif guna memperoleh manfaat yang lebth optimal dan lestari.

Permintaan terhadap produk rumput laut baik di tingkat pasar domestik maupun pasar intemasional cukup prospektif. Peningkatan produksi perikanan di kawasan ini selama 5 tahun terakhir cukup signifikan. Dari data tersebut, produksi rumput laut di daerah ini temyata mengalami fluktuasi dari tahun ke tahun (Anonim. 2006).

Desa Sandi merupakan salah satu desa yang ada di wilayah Kawasan Taman Nasional Wakatobi memiliki potensi budidaya memiliki potensi budidaya rumput laut seiuas 78 hektar dengan produksi rata-rata yang dicapai 1,7 ton (Anonim, 2007). Berdasarkan kondisi tersebut, maka kegiatan pemasaran rumput laut perlu dikembangkan lebih lanjut karena tanpa pemasaran 
yang baik kegiatan produksi juga akan terhambat.

Salah satu faktor yang mendukung adanya peningkatan pendapatan masyarakat pesisir adalah dukungan dalam sistem pemasaran dalam hal ini dalam proses terjadinya penentuan harga rumput laut. kurangnya perhatian dalam aspek pemasaran khususnya dalam hal fungsifungsi pemasaran sebagaimana yang diharapkan, sehingga efisiensi pemasaran selalu menurun. Operasi penjualan merupakan bagian yang terpenting dari operasi pemasaran yang dilakukan oleh masyarakat tani-nelayan secara keseluruhan. Namun dalam masyarakat tani-nelayan, banyak diantara mereka yang menglami kekecewaan dalam memsarkan hasil panennya, karena setiap produksi pada setiap musim tanam tidak disesuaikan dengan permintaan.

Kondisi dilematis sering dialami para petani dan konsumen khususnya dalam memilih tempat yang cocok dan tepat sesuai dengan kondisi lahan serta berorientasi pasar sehingga pengaiiran barang akan selalu saling mengimbangi. Petani sebagai produsen sangat membutuhkan barang dan jasa, tetapi apa yang mereka butuhkan tersebutmasih banyak yang belum tersedia, sehingga mereka cenderung untuk mengusahkan sendiri. Dalam hal ini, mereka harus memperoleh dari orang lain dan bahkan dari tempat yang jauh. Hal ini akan berdampak pada terjadinya jurang pemisah antara pihak produsen dengan konsumen, sementara untuk melancarkan pengaliran barang-barang dan jasa dari produsen ke konsumen tersebut diperlukan berbagai aktifitas seperti lembaga-lembaga yang berfungsi sebagai perantara.

Bagi petani yang mengusahakan rumput laut, secara sadar dan tanggap melihat dimana dan kapan mereka harus memasarkan produksinya, maka dengan sendirinya memperoleh imbalan yang mernuaskan. Sebaliknya, yang tidak tanggap dalam memilih tempat dan waktu yang tepat untuk memasarkan hasil panennya maka akan mengalami hambatan yang berakiba pada kegagalan (mengalami kerugian) dalam memasarkan hasil-hasil produk usahataninya.

Untuk mengantisipasi permintaan hasil rumput laut, maka masyarakat kawasan Taman Nasional Wakatobi telah berupaya mengembangkan usahatani rumput laut di daerahnya karena lingkungan alamnva cukup mendukung dan sangat potensial untuk mengembangkan usahatani tersebut. Dalam upaya pengembangan usahatani rumput laut ini, para petani kadangkala berhadapan dengan berbagai problem terkait dengan pengetahuan keterampilan. keterbatasan modal dan kendala pemasaran sehingga potensi ekonomi yang tersedia belum dapat dimanfaatkan secara optimal. Untuk memperoleh hasil yang optimal, maka semua faktor tersebut perlu mendapat perhatian, terutama masalah pemasaran yang sering dikeluhkan para petani karena faktor tersebut dapat mempengaruhi tingkat produktifitas dan perolehan pendapatan bagi petani rumput yang ada di Kawasan Taman Nasional Wakatobi.

Berdasarkan latar belakang di atas, maka permasalahan penelitian ini sebagai berikut :

1. Berapa besar pendapatan usanatni rumput laut di Desa Sandi Kecamatan Kaledupa SelatanKabupaten Wakatobi.

2. Berapa besar nilai keiayakan usahatani rumput laut di Desa Sandi Kecamatan Kaledupa SelatanKabupaten Wakatobi.

3. Bagaimana struktur pasar rumput laut di Desa Sandi kecamatan Kaledupa Selatan Kabupaten Wakatobi,

Berdasarkan rumusan masalah di atas, maka penelitian ini bertujuan untuk

1. Mengetahui besarya pendapatan yang diperoleh petani dari usahatani rumput laut di Desa Sandi Kecamatan Kaledupa Kabupaten Wakatobi.

2. Mengetahui besamya niiai keiayakan usahatani rumput laut di Desa Sandi Kecamatan Kaledupa Kabupaten Wakatobi.

3. Mengetahui struktur pasar rumput laut di Desa Sandi Kecamatan Kaledupa Kabupaten Wakatobi.

Manfaat yang diharapkan dari penelitian ini adalah:

1. Sebagai bahan masukan bagi Balai Taman Nasional Wakatobi dalam hal pembinaan 
masyarakat pesisir yang ada dalam kawasan Balai Taman Nasional Wakatobi.

2. Memberikan informasi kepada Masyarakat, terutama kepada Masyarakat Wakatobi dalam hal pengembangan rumput laut kedepan, guna memperoleh hasil yang lebih meningkat.

3. Sebagai bahan pertimbangan bagi pengembangan konsep/teori pertanian, khususnya dibidang agribisnis dan agroindustri serta penyuluhan pertanian.

4. Sebagai bahan informasi dan pembanding bagi penelitian lanjutan dengan skop yang lebih luas.

5. Sebagai bahan bacaan bagi para peneliti, khususnya mahasiswa Fakultas Pertanian yang berminat pada bagian Agribisnis.

\section{METODE PENELITIAN}

Penelitian ini dilaksanakan di Desa Sandi Kecamatan Kaledupa Kabupaten Wakatobi, yang berlangsung dari bulan Mei sampai bulan Juni 2016. Penetuan lokasi penelitian dilakukan secara purposive dengan pertimbangan sebagai berikut:

1. Desa Sandi cukup potensil untuk pengembangan budidaya rumput laut.

2. Desa Sandi merupakan salah satu sentra produksi rumput laut di Kecamatan Kaledupa Kabupaten Wakatobi

Populasi dalam penelitian ini adalah keseluruhan petani yang mengusahakan rumput laut berjumlah 50 orang. Penentuan sampel dilakukan dengan cara sensus dengan mengambil keseluruhan jumlah petani. Menurut Arikunto (1993), jika populasi diatas 100 orang maka dapat mengambil sampel $20 \%$ - 25\%, namun jika popolasi dibawah 100 orang maka mengambil sampel seluruhnya.

Data terbagi 2 (dua), yaitu data primer dan data sekunder. Data primer yaitu data yang diperoleh secara langsung dari sumber-sumber terpercaya di lokasi penelitian, yakni dengan melakukan observasi langsung ke obyek yang diteliti melalui wawancara (interview) kepada para responden atau informan dengan menggunakan kuisioner yang telah disiapkan sebelumnya. Hal ini dimaksudkan untuk memperoleh data atau keterangan yang jelas sehubungan dengan obyek penelitian ini.

Sedangkan data sekunder yaitu data yang diperoleh dari berbagai sumber, seperti literatur dan atau buku-buku perpustakaan, arsip-arsip/data-data yang ada pada obyek penelitian (Desa Sandi, KantorKecamatan Kaledupa dan Biro Pusat Statistik Wakatobi) serta referensi-referensi lainnya yang relevan

dengan obyek yang diteliti atau dikaji. Sumber data meliputi: orang, literature, dokumen dan suasana (observasi).

Variabel dalam penelitian ini adalah :

1. Identitas responden: umur, pendidikan formal, pengalaman berusahatani, jumlah tanggungan keluarga, luas lahan garapan.

2. Produksi rumput laut kering ( $\mathrm{Kg} / \mathrm{ha})$

3. Harga jual $(\mathrm{Rp} / \mathrm{Kg})$.

4. Biaya tetap dan biaya variabel.

5. Strukur pasar (jumlah penjual, jumlah pembeli, hambatan, jenis produk yang dihasilkan, hambatan masuk pasar).

Teknik pengolahan dan analisa data penelitian dianalisis secara deskriptif kualitatif dan kuantitatif. Analisis deskriptif kualitatif digunakan untuk menguraikan tentang karakteristik petani responden dan ushataninya. Sedangkan analisis deskriptif kuantitatif digunakan Analisis Pendapatan. Untuk mengetahui besarya pendapatan padi sawah dengan menggunakan rumus (Soeharjo dan Dahlan Patong, 1984):

$\mathrm{NI}=\mathrm{TR}-\mathrm{TC}$ 
$\mathrm{TR}=\mathrm{P} \times \mathrm{Q}$

$\mathrm{TC}=\mathrm{TFC}-\mathrm{TVC}$

Dimana :

$\mathrm{NI} \quad=$ Net Income (Pendapatan Bersih $(\mathrm{Rp})$

${ }_{T R} \quad=$ Total Revenue (Penerimaan Total) (Rp)

${ }_{T C} \quad=$ Total Cost (Biaya Total) $(\mathrm{Rp})$.

$\mathrm{P} \quad=$ Price (Harga Jual Produksi) $(\mathrm{Rp} / \mathrm{kg})$.

$\varrho \quad=$ Kuantitas (Jumlah Produksi) (kg)-

${ }_{T F C} \quad=$ Total Fixed Cost (Biaya Tetap Total) $(\mathrm{Rp})$.

${ }_{r v c}=$ Total Variable Cost (Biaya Variabel Total) (Rp).

Untuk mengetahui kelayakan usaha menggunakan analisis perbandingan Revenu-Cost ratio dengan membandingkan antara nilai produksi dengan biaya produksi (Soekartawi 1996) dengan rumus :

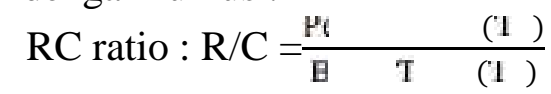

Kriteria:

$\mathrm{R} / \mathrm{C}>1$ : Hasil usahatani menguntungkan.

$\mathrm{R} / \mathrm{C}<1$ : Hasil usahatani tidak menguntungkan.

$\mathrm{R} / \mathrm{C}=1: \quad$ Hasil usahatani dikatakan impas.

Definisi Istilah mencakup pengertian atau batasan sehubungandengan pengumpulan data dalam rangka memudahkan penelitian di lapangan, antara lain:

1. Petani adalah orang yang mengusahakan rumput laut memproduksi pada saat musim panen (orang).

2. Produksi adaiah jumlah atau banyaknya rumput laut kering yang dihasilkan petani dalam satu musim tanam $(\mathrm{Kg})$.

3. Pendapatan adalah jumlah penerimaan yang diperoleh petani responden dari produksi rumput laut dalam satu musim tanam ( $\mathrm{Rp} / \mathrm{ha})$.

4. Tenaga keija adalah jumlah curahan tenaga kerja pada usahatani padi sawah ( $\mathrm{Rp} / \mathrm{hari})$.

5. Harga yang dimaksud adalah harga yang berlaku ditingkat petani.

6. Penerimaan usahatani rumput laut adalah produksi rumput laut dikali dengan harga jual ditingkat petani $(\mathrm{Rp} / \mathrm{ha})$.

7. Biaya usahatani rumpu laut adalah keseluruhan biaya yang dikeluarkan petani dalam menghasilkan rumput laut kering ( $\mathrm{Rp} / \mathrm{ha})$.

8. Pendapatan rumput laut adalah jumlah penerimaan diterima oleh petani dikurangi dengan biaya yang dikeluarkan dalam kurun waktu enam bulan.

\section{HASIL DAN PEMBAHASAN}

Penelitian yang dilakukan dengan menggunakan kuisioner terhadap 50 orang petani responden yang mengusahakan tanaman Rumput laut. Identitas petani responden menggambarkan factor-faktoryang mempengaruhi di dalammengelola usanataninya. Adapun identitas petani responden yang akan dijelaskan berdasarkan data primer yang diperoleh dari 50 orang petani responden meliput umur, pendidikan, pengalaman berusahatani, luas lahan dan jumlah tanggungan keluarga.

\section{Identitas petani responden}

a. Umur

Umur merupakan salah satu faktor yang mempengaruhi kemampuan fisik seseorang, baik dalam berpikir maupun dalam bekerja. Pada umumnya petani yang berumur muda mempunyai kemampuan fisik yang lebih besar dibanding petani yang lebih tua. Disamping itu, 
petani yang berumur lebih muda juga cenderung lebih cepat menerima hal-hal yang sifatnya baru, sehingga untuk mengimbangi kemampuan tersebut, petani yang berumur muda juga lebih dinamis dalam berusaha untuk memperoleh pengalaman baru dalam berusahatani. Sedang petani yang berumur tua umumnya lebih bersikap hati-hati karena memiliki kapasitas berusahatani yang lebih matang serta pengalaman yang cukup dalam mengelola usahatani. Akibatnya, mereka kurang dinamis dan cenderung tertutup terhadap hal-hal baru yang dianjurkan karena mereka selalu berpatokan pada sesuatu yang telah lewat.

Berdasarkan pengolongan umur tersebut, untuk satu bidang pekerjaan yang diiakukan seseorang tidak semuanya sama, termasuk dalam bidang pertanian. Sebagaimana Soehardjo dan Patong (1984), bahwa umur produktif manusia berkisar antara 15 sampai 54 tahun sedangkan yang non produktif diatas 54 tahun. Mengenai sebaran umur petani responden dari kegiatan usahatani yang dilakukan disajikan pada Tabel 1 sebagai berikut

Tabel 1. Pengelompokkan Responden Menurut Produktif dan Kurang Produktif di Desa Sandi Kecamatan Kaledupa Selatan Tahun 2016.

\begin{tabular}{cccc}
\hline No & Umur Responden (Tahun) & Jumlah (Orang) & Persentase $(\%)$ \\
\hline 1. & $23-54$ & 45 & 90,00 \\
\hline 2. & $55-60$ & 5 & 10,00 \\
\hline & Jumlah & 50 & 100,00 \\
\hline
\end{tabular}

Pada tabel 1. Menunjukkan bahwa sebanyak 45 orang atau $90 \%$ petani responden berada pada kelompok umur produktif (23-54 tahun), dan 5 orang atau $10 \%$ petani responden merupakan usia produktif . Ini menjukkan bahwa hanya sebagian kecil petani responden sudah tidak produktif lagi, namun dari segi pengalaman mereka lebih unggul.

\section{b. Pendidikan}

Pendidikan petani responden pada dasarnya akan mempengaruhi cara berpikir, khususnya dalam mengambil keputusan mengenai usatatani dengan berbagai pertimbangan. Dengan pendidikan yang tinggi dapat dengan mudah menerima inovasi baru atau selalu berpikir rasional terhadap perkembanganusahataninya serta kecenderungan seseorang untuk respon terhadap hal-hal baru yang sangat ditentukan oleh cara berpikir orang tersebut, yang semuanya sangat dipengaruhi dan ditentukan oleh latar belakang pendidikannya. berikut:

Adapun tingkat pendidikan formal petani responden dapat dilihat pada Tabel 2 sebagai

Tabel 2. Keadaan Pendidikan Petani Responden di Desa Sandi Kecamatan Kaledupa Selatan Tahun 2016.

\begin{tabular}{cccc}
\hline No & Tingkat Pendidikan & Jumlah (orang) & Persentase (\%) \\
\hline 1. & Tamat SD & 10 & 20,00 \\
\hline 2. & Tamat SMP & 16 & 32,00 \\
\hline 3. & Tamat SMA & 23 & 46,00 \\
\hline 4. & S1 & 1 & 2,00 \\
\hline & Jumlah & 50 & 100,00 \\
\hline
\end{tabular}




\section{J ournal of Agribusiness Media}

Vol. 1 I ssue 1, November 2017

P-ISSN: 2527-8479

Tabel 2 terlihat bahwa tingkat pendidikan petani responden terbanyak adalah tamatan SMA sebanyak 23 atau $46 \%$ petaniresponden yang tarnat SMP sebanyak 16 orang ataau 32\%, petani responden yang menamatkanpendidikanya dijenjang SD sebanyak 10 orang atau $20 \%$ dan yang terkecil adalah tamatan Sarjana (S1) sebanyak 1 orang atau 2\%, Ini berarti secara keseluruhan responden telah mengenyam pendidikan formal. Dengan pendidikan yang cukup memadai diharapkan dapat menunjang proses penyerapan dan penerapan teknologi baru khususnya pada teknologi budidaya runput laut.

c. Pengalaman Berusahatani

Pengalaman merupakan pendidikan yang dimiliki seseorang melalui rutin itas hidupnva sehari- hari. Petani dengan pengalaman yang dimiliki akan lebih baik dalam melakukan pekerjaan usahataninya. Dan lebih terampil dalam mengalokasikan waktu dan input produksi yang dimiliki.

Disamping itu, mereka juga lebih mampu dibanding petani lain yang belum berpengalaman, khususnya dalam hal mengkombinasikan faktor-faktor produksi yang jumlahnya terbatas secara optimal untuk menghasilkan produksi dan pendapatan yang tinggi. Untuk mengetahui pengalaman berusahatani petani responden, secara jelas disajikan pada Tabel 3 sebagai berikut:

Tabel 3. Keadaan Pengalaman Berusahatani Responden di Desa Sandi Kecamatan Kaledupa Selatan Tahun 2016.

\begin{tabular}{cccc}
\hline No & Pengalaman Berusatani (Tahun) & Jumlah (orang) & Persentase (\%) \\
\hline 1. & $2-4$ & 6 & 12,00 \\
\hline 2. & $5-10$ & 18 & 36,00 \\
\hline 3. & $11-23$ & 26 & 52,00 \\
\hline & Jumlah & 50 & 100,00 \\
\hline
\end{tabular}


Pada Tabel 3 nampak bahwa pengalaman berusahatani petani responden yang paling banyak berada pada interval 11-23 tahun sebanyak 26 orang atau 52,\%. Petani yang memiliki pengalaman 5-10 tahun sebanyak 18 orang atau 36\% sedangkan petani yang memiliki pengalaman kurang dari 5 tahun sebanyak 6 orang petani atau 12\%.n. Ini berarti bahwa ratarata petani responden telah dapat dikatakan berpengalaman SebagaimanaSoehardjo dan Patong (1984) bahwa seseorang dapat melakukan kegiatan usahatani dengan baik apabila telah memiliki pengalaman antara 10 sampai 20 tahun. Dari data di atas diharapkan para petani akan semakin giat dalam berusaha. khususnya dalam mengelola usahataninya.

\section{d. Jumlah Tanggungan Keluarga}

Jumlah tanggungan keluarga adalah banyaknya orang yang tinggal daiam satu keluarga yang secara langsung jadi tanggungan kepala keluarga ataupun yang berada di luar rumah tetapi hidupnya masih menjadi tanggungan kepala keluarga yangbersangkutan. Tanggungan keluarga yang dimaksud adalah suami, istri dan anak (Soehardjo dan Patong, 1984).

Jumlah tanggungan keluarga yang besar disamping mempengaruhi kreatifitas dalam mengelola usahataninya, juga akan berpengaruh pada pendapatan dan kesejahteraan keluarga tani itu sendiri. Hal ini dimungkinkan terutama bila jumlah tanggungan keluarga tersebut berada dalam golongan usia produktif, sehingga akan memungkinkan tersedianya tenaga kerja yang dapat dimanfaatkan dalam kegiatan usahatani.

Menurut Soeharjo dan Patong (1984), bahwa yang termasuk jumlah tanggungan keluarga kccil yaitu berkisar 3-4 orang, sedangkan jumlah tanggungan keluarga $>5$ orang termasuk jumlah tanggungan keluarga besar.

Berdasarkan hasil penelitian bahwa sebagian besar petani responden tanggungan keluarganya berkisar antara 1-4 jiwa sebanyak 40 orang atau 80\% dan 5-86 jiwa sebanyak 10 orang atau $20 \%$. Kondisi demikian dapat dikatakan bahwa jumlah tanggungan keluarga yang ada di lokasi penelitian sebagian besar (80\%) termasuk memiliki jumlah tanggungan keluarga kecil sehinggga untuk mememuhi kebutuhan tenaga kerja pada usahataninya membutuhkan tenaga kerja luar keluarga. Hal ini karena kebutuhan tenaga kerja keluarga belum kebutuhan dalam melakukan kegiatan proses produksi usahataninya. Jumlah tanggungan keluarga petani responden dalam penelitian ini disajikan pada Tabel 4 sebagai berikut:

Tabel 4. Keadaan Jumlah Tanggungan Keluarga Petani Responden di Desa Sandi Kecamatan Kaledupa Selatan Tahun 2016.

\begin{tabular}{cccc}
\hline No. & Jumlah Tanggungan Keluarga (orang) & $\begin{array}{l}\text { Jumlah } \\
\text { (orang) }\end{array}$ & Persentase (\%) \\
\hline 1. & $1-4$ & 40 & 80,00 \\
\hline 2. & $5-8$ & 10 & 20,00 \\
\hline & Jumlah & 50 & 100,00 \\
\hline
\end{tabular}

Berdasarkan hal tersebut di atas menunjukkan bahwa tanggungan keluarga yang besar maupun yangkecil diharapkan akan mampu rneningkatkan hasil produksiusahatani, khususnya usahatani rumput laut, sekaligus dapat rneningkatkan taraf hidup keluarga tani.

e. Panjang tali

Luas lahan garapan merupakan faktor produksi yang sangat penting artinya dalam melakukan usaha pertanian. Hal tersebut sebagaimana yang dikemukakan oleh Soehardjo dan Patong (1984), bahwa tanah merupakan ibu usahatani karena di sanalah keluarnya produk melalui proses produksi. Disamping itu, penguasaan petani terhadap sumber daya lahan yang dimiliki 
akan menentukan produktifitas dan pada gilirannya menentukan pendapatan usahatani. Dengan demikian, luas tingkat pendapatan yang diperoleh petani dari usahatani yang dikelolanya. Gambaran penguasaan lahan petani dapat dilihat pada Tabel 5.

Tabel 5. Keadaan Panjang Tali Pada Usaha Budidaya Rumput Laut di Desa Sandi Kecamatan Kaledupa Selatan.

\begin{tabular}{cccc}
\hline No & Panjang Tali (M) & Jumlah (orang) & Persentase $(\%)$ \\
\hline 1. & $400-1.700$ & 32 & 64,00 \\
\hline 2. & $1.701-3.000$ & 18 & 36,00 \\
\hline & Jumlah & 50 & 100,00 \\
\hline
\end{tabular}

Berdasarkan Tabel 5 diperoleh hasil penelitian petani yang mengusahakan budidaya rumput laut dengan panjang tali berkisar antara 400 meter - 1,700 meter sebanyak 32 orang atau 64\% sedangkan dengan panjang tali berkisar antara 1.701 meter sampai dengan 3.000 meter sebanyak 18 orang atau $36 \%$. Ini berarti diharapkan petani dalam megelola uataninya hendaknya dilakukan dengan intensif dengan penerapan teknologi atau metode baru serta memanfaatkan sumber daya yang ada secara optimal, sehingga dapat meningkatkan produksi petani dari usahatani yang dikelolanya.

Deskripsi usahatani merupakan gambaran keadaan usahatani petani responden dalam melakukan kegiatan atau aktivitas usahataninya.

\section{Deskripsi Usahatani}

a. Produksi

Produksi (output) merupakan salah satu faktor atau komponen yang turut menentukan penerimaan suatu usahatani. Sebagaimana Mubyarto (1972) bahwa produksi adalah banyaknya hasil fisik yang dapat diperoleh dari satu kesatuan faktor produksi (input). Oleh karena itu, setiap petani senantiasa berupaya meningkatkan produktifitasusahatani yang diusahakannya,sehingga dapat memberikan produk dan pendapatan yang lebih baik. Dengan demikian maka produksi merupakan harapan bagi setiappetani dalam mengelolausahataninya. Jadi, produksi usahatani merupakan hasil kerjasama dari faktor-faktor produksi yang dimiliki.

Produksi yang dimaksud adalah hasil rumput laut kering yang dihasilkan selama satu musim tanam. Mengenai tingkat produksi rumput laut petani responden di Desa Sandi Kecamatan Kaledupa Selatan disajikan pada Tabel 6 berikut:

Tabel 6. Tingkat Produksi Rumput Laut Kering Petani Responden Di Desa Sandi Kecamatan Kaledupa Selatan Tahun 2016.

\begin{tabular}{cccc}
\hline No & Produksi $(\mathrm{Kg})$ & Jumlah (orang) & Persentase (\%) \\
\hline 1. & $300-950$ & 38 & 94,00 \\
\hline 2. & $951-1.600$ & 12 & 6,00 \\
\hline & Jumlah & 50 & 100,00 \\
\hline
\end{tabular}

Pada Tabel 6 narnpak bahwa jumlah produksi yang diperoleh para petani responden antara 300 $\mathrm{Kg}-950 \mathrm{Kg}$ sebanyak 38 orang atau $94 \%$, jumlah produksi yang diperoleh petani responden antara 951-1.600 Kg sebanyak 12 orang atau 6\%. Rendahnya produksi yang dihasilkan tersebut oleh beberapa faktor yang mempengaruhi seperti belum dimanfaatkanya teknik pembididaya 
rumput laut, kemampuan petani mengelolah kegiatan usahataninya, adanya serangan hama penyakit pada rumput laut

Hasil produksi yang dihasilkan tersebut selanjutnya dijual untuk mendapatkan sejumlah uang tunai yang digunakan untukkeperluan sehari-hari dan untuk disimpan sebagai modai usaha lainnya.

b. Biaya Produksi

Biaya Produksi adalah semuapetani untuk keperluan usahataninya ang dinilai dengan uang (rupiah). Biaya produksi yang dimaksud dalam penelitian ini adalahkeseluruhan biaya yang dikeluarkan oleh petani selama melakukan kegiatan usahatani. Dalam hal ini biaya yang dikeluarkan hanya biaya tetap dan biaya variabel. Untuk lebih jelas mengenai biaya yang dikeluarkan petani responden dalam budidaya rumput laut disajikan dalam Tabel 7 sebagai berikut:

Tabel 7. Biaya Rata-Rata Uaha Rumput Laut Petani Responden Di Desa Sandi Kecamatan Kaledupa Selatan Tahun 2016.

\begin{tabular}{clc}
\hline No & \multicolumn{1}{c}{ Jenis biaya (Rp) } & Jumlah $(\mathrm{Rp})$ \\
\hline 1. & Penyusutan alat & 162.000 \\
\hline 2. & Bibit & 636.000 \\
\hline 3. & Upah tenaga & 895.000 \\
\hline 4. & Kerja & 78.800 \\
\hline 5. & Pengangkutan karung & 64.400 \\
\hline \multicolumn{2}{r}{ Jumlah } & Rp. 1.836 .830 \\
\hline
\end{tabular}

Pada Tabel 7 nampak bahwa biaya rata-rata penyusutan alat sebesar Rp. 162.000, biaya pembelian bibit sebesar Rp. 636.000, pengelaran upah tenaga kerja sebesar Rp 895.000, pengangkutan Rp. 78.800 dan pembeieiian karung sebesar 64.400 sehingga secara keseluruhan rata-rata biaya yang dikeluarkan oleh petani dalam membudidayakan rumput laut sebesar Rp. 1.836 .830 .

c. Harga Produksi

Harga produksi merupakan ukuran atau takaran untuk menentukan nilai suatu barang atau produk yang ditawarkan atau dijual. Besar kecilnya harga juga sangat menentukan pendapatan yang diperoleh petani. Semakin tinggi harga yang ditawarkan ke konsumen maka semakin besar pula nilai atau pendapatan yang diterima produsen atau petani. Untuk harga produksi rumput laut kering di tingkat petani dalam penelitian ini ditetapkan rata-rata sebesar Rp. 8.500/Kg.

d. Pendapatan

Pendapatan yang dimaksud dalam penelitian ini adalah selisih antara jumlah penerimaan dengan seluruh biaya produksi yang dikeluarkan dalam satu kali proses produksi dalam setahun. Pendapatan yang diperoleh petani responden dalam penelitian ini yaitu penerimaan dikurangi biaya produksi yang digunakan selama musim panen terakhir. Pendapatan rata-rata yang diperoleh sebesar 5.576.000 dalam waktu 6 bulan. Untuk lebih jelas mengenai pendapatan petani responden disajikan alam Tabel 8 sebagai berikut:

Tabel 8. Tingkat Pendapatan Usahatani Rumput Laut Di Desa Sandi Kecamatan Kaledupa Selatan Tahun 2016. 


\begin{tabular}{cccc}
\hline No & Tingkat Pendapatan & Jumlah (Orang) & Persentase (\%) \\
\hline 1. & $1.680 .000-4.977 .000$ & 35 & 70,00 \\
\hline 2. & $4.997 .001-8.452 .000$ & 15 & 30,00 \\
\hline & Jumlah & 50 & 100,00 \\
\hline
\end{tabular}

Pada Tabel 8 nampak bahwa sebagian besar petani responden memiliki pendapatan bersih Rp. 1.680.000 sampai Rp. 4.997.000. Sebanyak 35 orang atau 70\%, sedangkan petani responden yang memiliki pendapatan bersih berkisar antara Rp. 4.997.000 sampai dengan Rp. 8.452.000 sebanyak 15 orang atau $30 \%$. Ini menujukkan bahwa pemenuhan kebutuhan minimum seharihari sudah lebih dari cukup. Sebagaimana yang dikemukakan oleh Sajogyo (1996), bahwa untuk wilayah pedesaan, standar kebutuhan minimum rata-rata yang ditetapkan jika dinilai dengan uang adalah sebesar 240.000 rupiah/bulan. Sedangkan Badan Pusat Statistik Indonesia (2004), mencatat kemiskinan penduduk provinsi Sulawesi Tenggara sebesar Rp. 128.667 perkapital perbulan.

Berdasarkan kriteria tersebut di atas berarti bahwa pada umumnya petani responden yang ada di Desa Sandi telah memenuhi syarat, atau dengan kata lain untuk satu kegiatan budidaya rumput laut diperoleh pendapatan sebesar Rp. 929.333 perkapita/bulan. dengan demikian di wilayah tersebut sudah mampu memenuhi kebutuhan hidup kemikinan.

\section{Analisis Kelayakan usaha Rumput Laut}

Berdasarkan hasil penelitian dan analisis data untuk mengetahui kelayakan usaha rumput laut yang dibudi dayakan oleh responden diperoleh nilai kelayakan sebesar 3,02. Untuk mengetahui nilai kelayakan sebagai berikut:

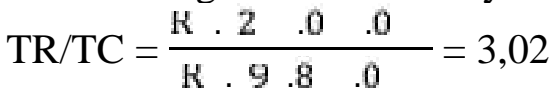

Nilai tersebut menunjukan bahwa setiap biaya yang dikeluarkan oleh responden sebesar Rp. 1 akan memberikan penerimaan sebesar Rp 3,02, dengan demikian dapat dikatakan bahwa usaha budidaya rumput laut yang dilakukan oleh responden yang ada di desa Sandi Kecamatan Kaledupa Selatan layak untuk diusahakan dan dikembangkan lebih besar dengan teknik budiadaya yang tepat.

\section{Struktur Pasar}

Struktur pasar rumput laut di daerah penelitian dapat diidentifikasi dengan melihat jumlah lembaga pemasaran yang terlibat, sifat produk, sumber informasi dan hambatan keluar masuk pasar. Uraian mengenai struktur pasar yang dihadapi oleh para pelaku pasar dalam pemasaran rumput laut di Desa Sandi adalah sebagai berikut:

a. Petani

Struktur pasar yang dihadapi oleh petani rumput laut cendenmg mengarah kepada pasar oligopsoni. Hal ini dikarenakan jumlah lembaga pemasaran rumput laut tidak sebanding dengan jumlah petani. Jumlah petani lebih banyak dibandingkan jumlah pedagang pengumpul desa. Sedikitnya jumlah pedagang pengumpul desa menyebabkan harga lebih banyak ditentukan oleh pedagang pengumpul, sehingga petani hanya bertindak sebagai price taker akibat posisl tawar yang lemah walaupun dalam proses transaksi dilakukan secara tawarmenawar. Petani dalam hal ini belum mampu menghitung keuntungan yang dia peroleh jika melakukan penjualan sendiri ke pasar atau dengan adanya kendala modal yang relatif besarjika melakukan penjualan sendiri. Komoditi yang diperjualbelikan bersifat homogen yaitu jenis rumput laut satonik yang berwama merah. Untuk informasi pasar diperoleh dari sesame petani, pedagang pengumpul desa.

b. Pedagang Pengumpul Desa 
Pedagang pengumpul desa menghadapi struktur pasar oligopsoni. Hal ini dihadapkan pada jumlah pedagang besar (eksportir) yang berjumlah 2 orang. Hambatan masuk bagi pedagang pengumpul desa terletak pada modal yang harus digunakan untuk membeli rumputlaut kering dari petani. Komoditi yang diperjualbelikan bersifat homogen yaitu rumput laut jenis satonik. Proses penentuan harga didasarkan pada proses tawar-menawar dengan informasi harga yang diperoleh.

c. Pedagang

Struktur pasar yang dihadapi oleh pedagang Besarr bersifat oligopoli. Komoditi yang diperjualbelikan bersifat homogen dan jumlah pedagang besar dibandingkan jumlah konsumen yang sangat banyak. Skala usaha pedagang besar (pengusaha) relatif besar dan pedagang besar (eksportir) mudah memasuki atau meninggalkan pasar. Apabila pedagang besar tidak memperoleh keuntungan, maka pedagang besar dapat meninggalkan usaha tersebut.

\section{KESIMPULAN DAN SARAN}

\section{a. Kesimpulan}

Berdasarkan hasil analisis dan pembahasan, maka dapat dikemukakan beberapa kesimpulan sebagai berikut:

1. Pendapatan rata-rata petani dari usahatani rumput laut dengan panjang tali rata-rata 1.277 meter sebesar Rp. 5.576.000 tiap 6 bulan, dengan pendapatan Rp. 929.333 perkapita perbulan.

2. Analisis kelayakan usahatani rumput laut diperoleh nilai sebesar 3,02 nilai tersebut menunjukan budidaya rumput laut yang diusahakan oleh petani di Desa Sandi Kecamatan Kaledupa Selatan menguntungkan untuk diusahakan.

3. Struktur pasar yang dihadapi oleh masing-rnasing lernbaga tataniaga berbeda-beda. Petani, dan pedagang pengumpul Desa menghadapi struktur pasar oligopsoni. Sedangkan struktur pasar yang dihadapi oleh pedagang besar (eksportir) mengarah ke pasar oligopoli.

b. Saran

Berdasarkan kesimpulan di atas, dapat dikemukakan beberapa saran sebagai berikut:

1. Hendaknya petani dalam melakukan kegiatanusahataninya perlu pengelolaan usahatan yang lebih baik, diantaranya dengan memberikan input produksi terutama pemupukan sehingga dapat menghasilkan produksi yang maksimal dan pendapatan yang diterima oleh petani juga meningkat.

2. Sebaiknya pemerintah daerah Kabupaten Buton menetapkan harga dasar minimum rumput laut untuk melindungi petaniselaku penghasil rumput laut dari fluktuasi harga yang terjadi di pasaran yang disebabkan oleh beberapa faktor, antara lain faktor iklim dan permainan harga oleh tengkulak.

3. Bagi petugas PPL setempat, kiranya perlu untuk rneningkatkan lagi kegiatan penyuluhan pertanian kepada para petani khususnya untuk komoditi-komoditi unggulan daerah setempat, sehingga mampu rneningkatkan pendapatan dan kesejahteraan petani.

4. Disarankan kepada petani setempat agar menjalin hubungan kerjasama dengan berbagai pihak, baik antara petani dengan kelompok tani, PPL, Pemerintah setempat serta pemilik modal.

\section{DAFTAR PUSTAKA}

AM. Musa Pasaribu, 2004. Studi Pembangan Ekspor Rumput (Euchemma Cottomi) Studi Kasus pada PT. Bantimurung Indah. Jurnal Sosial Ekonomi Perikanan Hasanuddin.

Azzaino,Z. 1982. Pengantar Tata Niaga Pertanian. Bahan Kuliah Jurusan Sosial Ekonomi Pertanian Bogor. 
Anam Gafar, 2005. Analisis Produksi Petani Rumput Laut di Kelurahan Bintarore Kecamatan Ujung Bulu Kabupaten Bulukumba. Program Pasca Sarjana Universitas Hasanuddin Makasar.

Anggadiredja JT, Zatnika A, Purwoto H. dan Istini S., 2006. Rumput Laut. Penebar Swadaya. Jakarta.

Aslan, L.M. 1998. Budidaya RumputLaut. Yogyakarta. Penerbit Kanisius. Penebar Swadaya.

Aslan. 1991. Petnujuk dan Pengusahaan Bertanam Rumput Laut. Direktorat Bina Produksi. Direktorat Jendral Pertanian, Jakarta.

Dahal, D.C dan Hammood.1977. Market and Price Analysis The Agricultural Industris. Me Graw Hill, Inc. Unitet State.

Ditjenkan Budidaya, 2005. Profil Rumput Laut Indonesia. Direktorat Perikanan Budidaya, Departemen Kelautan dan Perikanan. Jakarta.

Departemen Kelautan dan Perikanan. 2001.

Duncan, 2005. Desain program keterlibatan masyarakat di tingkat kecamatan dalam pengelolaan sumberdaya pesisir Kaledupa. Laporan, dalam mendukung program COREMAP di Gugus Pulau Kaledupa.

Hidayat, A. 1990. Budidaya Rumput Laut. Penerbit Usaha Nasional. Surabaya.

Hidayati D, Ngadi, DaSiyo. 2007. Konsidi sosial - ekonomi masyarakat di lokasi CGREMA II: kasus Kabupaten Wakatobi. CRIT - LiPI. Jakarta.

Jamal, E, 1992. Aspek-Aspek Ekonorni Pengembangan Usaha Budidaya Rumput Laut di Indonesia. Forum Penelitian Agro Ekonorni.

Limbong dan Sitorus, 1987.Pengantar Tata NiagaPertanian. Dikiat Jurusan Ilmu-Ilmu SosialEkonorni Pertanian. 1PB.

Mubiarto, 1979.Pengantar EkonorniPertanian. LP3S. Jakarta.

Mubarok, 1991. Potensi Produksi Karaginofit Indonesia Presiding Temu Karya Ilmiah Pasca Panen Rumput Laut Sub Baiai Penelitian.

Mc. Hugh Dj, 2003. A Guide toSeawed Industry, FAO Fiheris Technical Paper.

Nasuddin, Wasrob, 2002. Tatat Niaga Pertanian Universitas Terbuka. Jakarta.

Nazir M. 2003. Metode Penelitian. Ghailia Indonesia. Jakarta.

Notohadinegoro T, 1999. Lingkungan Kalimantan: Peluang dan Kandala Bagi Pengelolaannya. Jumal Pusat PenelitianLingkungan Hidup. No. 17 Tahun VI. UGM. Yogyakarta. Nijman, HJ dan Van Dework, 1983. Strategi PemasaranModem. Eriangga.

Perikanan Rumput Laut Slipi Pusat Penelitian dan Pengembangan Perikanan Badan Penelitian dan Pengembangan Perikanan Departemen Pertanian. Jakarta.

Panglaykirn dan HaziS. 1960. Marketing Suatu Pengantar PT. Pembangunan Djakarta.

Soekartawi, et al. 1986. Ilmu Usahatani dan Penelitian Untuk Pengembangan Petani Kecil. U1Press. Jakarta.

Soekartawi, 1987. Prinsip-Prinsip Ekonorni Pertanaian (Teori dan Apiikasinya), Rajawali Press. Jakarta. 